\title{
GAUGING THE ACCEPTANCE AND ATTITUDES OF RURAL WORKERS IN THE SEMIARID REGION OF NORTHEASTERN BRAZIL CONCERNING THE ARTISANAL PRODUCTION AND CONSUMPTION OF SPIRULINA PLATENSIS
}

\author{
Jordana Kaline da Silva Santana ${ }^{1,2 *}$, Cristiane Francisca da Costa Sassi ${ }^{2}$, Viviany Silva Pessoa ${ }^{3}$, Katharina \\ Kardinele Barros SAssi ${ }^{4}$, Roberto SAssi ${ }^{2}$
}

\begin{abstract}
1 Programa de Pós Graduação em Produtos Naturais e Sintéticos Bioativos, Universidade Federal da Paraíba
2 Departamento de Sistemática e Ecologia, Laboratório de Ambientes Recifais e Biotecnologia com Microalgas, Universidade Federal da Paraíba

3 Departamento de Psicopedagogia, Núcleo de Estudos em Desenvolvimento Humano, Educacional e Social, Universidade Federal da Paraíba

4 Departamento de Engenharia de Alimentos, Laboratório de Análise Sensorial, Universidade Federal da Paraíba.

* Autor para correspondência: jordanakaline_21@hotmail.com
\end{abstract}

Recebido em 12 de março de 2017. Aceito em 28 de julho de 2019. Publicado em 26 de setembro de 2019.

\begin{abstract}
Aвstract - The purpose of this study was evaluate the acceptability of $S$. platensis in feeding of seventy-five rural workers in the municipality of Frei Martinho, semiarid region of Paraiba, Brazil. It was evaluated their attitudes in terms of the possibility of cultivating that microalgae, if they would be open to dietary changes (innovative attitudes) or refractory to it (conservative attitudes), and their attitudes towards possible artisanal cultivation of $S$. platensis. The biomass produced in laboratory cultures was used for producing cakes, juices, and cookies; in natura or dried materials were also tested for acceptability, as well as their purchase intention of products based on Spirulina. Acceptability index higher than expected $(70 \%)$ were observed for all of the attributes evaluated (appearance, odor, and texture) in three different presentations ("in natura", dried, and incorporated into foods), except for the odor in the in natura form $(66.12 \%)$. In terms of purchase intention, $88 \%$ of the respondents confirmed that they would buy supplemented products if they were available. The attitude tests showed a consistent internal positive view of Spirulina, indicating that the agricultural workers were open to technological innovations.
\end{abstract}

KEYwORDs: Microalgae; Artisanal cultivation; Food supplements; Alternative diets.

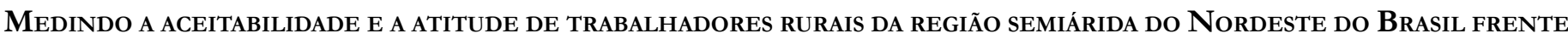
À PRODUÇão ARTESANAL E CONSUMO DE SPIRULINA PLATENSIS

Resumo - Objetivou-se com este trabalho, avaliar a aceitabilidade quanto ao uso da $S$. platensis na alimentação de 75 trabalhadores rurais do município de Frei Martinho-PB, região semiárida da Paraíba, Brasil. Foi medida a atitude frente a possibilidade de implantação de cultivo familiar, visando avaliar se os agricultores estão abertos (atitude inovadora) ou se são refratários (atitude conservadora) a mudanças e também quanto a sua atitude frente ao cultivo artesanal de $S$. platensis. A biomassa produzida em cultivos laboratoriais foi usada na preparação de bolos, sucos e biscoitos e nas versões in natura e seca para análise sensorial do teste de aceitabilidade e intenção de compra de produtos à base de $S$. platensis. Índices de aceitabilidade superiores ao esperado (70\%) foram observados para todos os atributos testados (aparência, odor e textura) nas três versões (in natura, seca e em alimentos), exceto para odor na forma "in natura" (66,12\%). Quanto à intenção de compra, $88 \%$ dos entrevistados afirmaram que comprariam os produtos. Os testes de atitudes evidenciaram um índice de consistência interno positivo frente à Spirulina, indicando que os agricultores são abertos a inovações tecnológicas.

Palavras-Chave: Microalgas; Cultivo artesanal; Suplemento alimentar; Alimentos alternativos. 


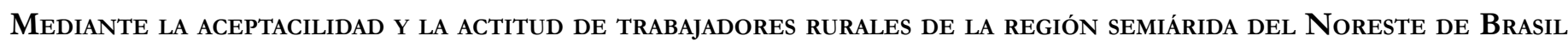
FRENTE A LA PRODUCCión ARTESANAL y CONSUMO DE SPIRULINA PLATENSIS

RESUMEN - Este trabajo tuvo como objetivo, evaluar la aceptabilidad en cuanto al uso de $S$. platensis en la alimentación de 75 trabajadores rurales del municipio de Frei Martinho-PB, región semiárida de Paraíba, Brasil. Se midió la actitud ante la posibilidad de aplicación de la agricultura familiar, para evaluar si los agricultores están abiertos (actitud innovadora) o son refractarios (actitud conservadora) para cambios y también se evaluaron para determinar su actitud ante el cultivo artesanal de $S$. platensis. La biomasa producida en cultivos de laboratorio se utilizó en la preparación de pasteles, jugos y galletas y en las versiones in natura y seca para el análisis sensorial y pruebas de aceptabilidad e intención de compra de productos a base de Spirulina. La aceptabilidad tasa superior a la esperada (70\%) se observaron para todos los atributos evaluados (aspecto, olor y textura) en tres versiones (in natura, secos, y en alimentos), excepto por el olor en la forma in natura (66,12\%). En cuanto a la intención de compra, el 88\% de los encuestados afirmaron que comprarían el producto. Pruebas de aceptabilidad mostraron un índice de consistencia interno positivo frente a la Spirulina, lo que indica que los agricultores están abiertos a las innovaciones tecnológicas.

Palabras Clave: Microalgas; Cultivo artesanal; Complemento alimenticio; Alimentos alternativos.

\section{INTRODUCTION}

Alternative foods that could reduce nutritional deficiencies using new processes and new raw materials have been examined in many recent research projects, including the insertion of microorganisms or enzymes into foodstuffs and the availability of interesting new products. Within this context, the cyanobacterium Arthrospira platensis (Spirulina platensis) stands out due to its high protein content (55-70\% of its dry weight) and the presence of polyunsaturated fatty acids, pigments, mineral salts and vitamins (Konícková et al. 2014; FAO 2008).

Spirulina platensis (order Oscillatoriales) is a microscopic, photosynthetic, unicellular, filamentous blue-green cyanobacterium that grows in alkaline waters, and is composed of spiral trichomes 5-6 $\mu \mathrm{m}$ wide and 20-200 $\mu \mathrm{m}$ long (Hoff and Snell 1999). This cyanobacterium is intensively cultivated in many different countries, and its biotechnological applications have been directed toward human health - as therapeutic and nutritional supplements, as a natural source of $\gamma$-linolenic acid and antioxidant pigments such as carotenoids, vitamins (especially vitamin B12 and pro-vitamin A - $\beta$-carotene), and minerals (such as iron) (Belay 2002).

This nutritional supplement has been especially effective in treating undernourished children (Simpore et al. 2006); Spirulina has also been shown to act as an immunomodulator in humans and animals, with indications that extracts of this cyanobacterium can impede or even inhibit cancer (Konícková et al. 2014). Spirulina also shows antimicrobial activity (Ozdemir et al. 2004), stimulating the secretion of Interleucine (IL)-1 $\beta$, IL-4 and interferon (IFN)- $\gamma$ by 2.0. 3.3 and up to 13.6 times basal levels, respectively, indicating its potential in protection against pathogens and intracellular parasites; it may also be effective in combating extracellular parasites (Mao et al. 2003). Additional possible uses of Spirulina for human health purposes include antiviral treatments (Ramakrishnan, 2013), the inhibition of anaphylactic shock (Yang et al. 1997), hypolipidemics (El-sheekh et al. 2014), the prevention of diabetes and poor blood circulation (Layam et al. 2007; Oropeza et al. 2010), and combating heavy metal nephrotoxicity (Mohan et al. 2006).

For these reasons, Spirulina has been promoted as a "natural super supplement" (Moorhead et al. 2006), "a marvelous future source of food" (Habib et al. 2008) and "a powerful new food that can help rebuild our health and restore our environment" (Henrikson 2009). Spirulina produced by Earthrise has the status of GRAS (Generally Recognized as Safe) (FDA 2002). 
Spirulina is currently produced in many countries. Companies utilizing increasingly complex production systems and commercializing their products in diverse forms, like food shops and other such commercial sites throughout the world. The distance between the increasingly refined technological culturing of the species and its artisanal production is quite large. There is very little data available, however, concerning the acceptance of this species as an everyday food item that could improve the nutritional quality of needy communities.

In the present work, the microalgae Spirulina platensis was cultivated in closed systems with the objective of using it to enrich foodstuffs and analyzing its acceptability; it was also cultivated in artisanal open-tank systems for demonstration purposes. The acceptance of this product by low income farmers was investigated in the semiarid region of northeastern Brazil (the Caatinga biome) with the goal of gauging its degree of acceptance by local communities and, most importantly, its potential insertion into their diets as a new, non-traditional, food source.

\section{MATERIAL AND METHODS}

Production of Spirulina platensis biomass for tests of acceptability as a food source among farmers in the semiarid region of Paraiba State, Brazil

Zarrouk synthetic medium was used for the cultivation and maintenance of S. platensis (Zarrouk 1966), being prepared using sterile distilled water (left standing for 24 hours for re-oxygenation); the macronutrients, micronutrients, and vitamins of the culture media were then added. The $S$. platensis strain utilized (D9Z) was derived from the microalgae culture bank of the Laboratory of Reef Environments and Microalgae Biotechnology of the Federal University of Paraiba.

The cultures were maintained in sterile $20 \mathrm{~L}$ flasks in temperature controlled chambers $\left(25 \pm 2{ }^{\circ} \mathrm{C}\right)$ under a 12 hour daily illumination regime. Culture development was monitored for approximately 15 days using a TurnerDesign Fluorometer. Culturing was interrupted at the beginning of the stationary growth phase, and the microalgae biomass was then concentrated by centrifuging $\left(-18^{\circ} \mathrm{C}\right)$, frozen $\left(-30{ }^{\circ} \mathrm{C}\right)$, and subsequently lyophilized. An open tank cultivation system was also installed in the village of Quinturaré, in the municipality of Frei Martinho Paraíba for demonstration purposes.

\section{Microbiological analysis}

Microbiological analyses of the biomass of strain D9Z (Spirulina platensis) was undertaken to guarantee its quality as a food supplement for rural populations.

Analyses of the Most Probable Number of total coliform and thermotolerant coliform bacteria were undertaken, as well as tests for the presence of Salmonella and counts of Bacillus cerens and coagulase-positive Stafilococcus. These analyses were performed at the Laboratory of Microbiological Analyses in the Departmental of Technology and Food Chemistry, Federal University of Paraíba, following established methodologies (Brazil 2003). Based on the following standards of microbiological food evaluations (in conformity with resolution RDC $\mathrm{n}^{\mathrm{o}}$ 12, of February 2, 2001, of the National Agency of Health Monitoring): Coliform bacteria at $45^{\circ} \mathrm{C} / \mathrm{g}(\mathrm{MPN} / \mathrm{g})$ : 10; Salmonella sp/25g (CFU/g): absence; coagulase positive Staphylococcus /g (CFU/g): 5x10²; and Bacillus cereus/g (CFU/g): $5 \times 10^{2}$. The foods that were enriched included chocolate cake, acerola and pineapple fruit juice, and chocolate ice cream - all of which were industrialized and acquired in local markets. 


\section{Tests of acceptability and intention to purchase}

In order to measure the openness of rural agricultural workers to the acceptance of new enriched foodstuffs, Spirulina in natura and dry, and added to prepared foods (10\% biomass) were tested in sensorial evaluations by 75 volunteer tasters (unionized agricultural workers in the municipality of Frei Martinho, in the semiarid region of Paraíba State, Northeastern Brazil). Of these 41.3\% were males and 58.7\% were females, with ages between 18 and 65 years. Each taster was asked to sign an Agreement of Free Choice authorizing their voluntary participation in the research (after being informed about the nature of the research project, its objectives, and any potential risks and/or inconveniences it might entail). This research project was approved by the ethics committee of the Health Sciences Center at the Federal University of Paraíba (Protocol 095/14 CAAE:27984414.1.0000.5188)

The tests consisted of evaluating the acceptability and the possibility of consuming pre-prepared food products (chocolate cake, chocolate ice cream, and mixed pineapple and acerola juice) with added 10\% powdered Spirulina. The tasters were free to choose which type of food product they would evaluate. The volunteers were also asked to evaluate, but not to consume, fresh and dry lyophilized biomasses of Spirulina. All of the products were evaluated during a single session during visits to the homes of the rural workers when they evaluated the attributes of the foods: appearance, odor, texture, and an overall evaluation, using a nine point hedonic scale $(1=$ very much disliked, to $9=$ very much liked) (Stone and Sidel 1993). The tests of purchase intention utilized a five point hedonic scale varying from "would buy" (5) to "would not buy" (1). It was also analyzed the acceptability index (IA) of the products analyzed, considering $100 \%$ as the greatest possible overall grade, and considering as satisfactory acceptance indices those that were greater than or equal to $70 \%$ (Teixeira et al. 1987), using the equation: $\mathrm{IA}=(\mathrm{A} \times 100) / \mathrm{B}$, where $\mathrm{A}=$ median evaluation obtained, and $\mathrm{B}=$ maximum evaluation of the product.

The acceptance percentages and indifference or rejection of each attribute was calculated based on the results of the acceptance tests, utilizing the 9 point hedonic scale. Acceptance was calculated by summing the percentages of "somewhat liked" (6) to "very much liked" (9) scores; indifference was calculated as the percentage of the "didn't like/didn't dislike" (5) score; and rejection was calculated by summing the percentages of "slightly disliked" (4) to "greatly disliked" (1) scores.

The evaluations were undertaken utilizing standardized procedures designed to guarantee a minimum of biased responses through minimum possible interventions in the applications of the questionnaires. Explanations were made only when solicited, without comments concerning content, only form.

\section{Attitude tests}

Tests of attitudes concerning the installation of household culturing Spirulina evaluated the innovative (openness to change) or conservative attitudes (refractory to changes) of the agricultural workers in the semiarid region of Brazil, using an adaptation of the Thompson and Barton scale (1994), which is employed to measure human eco-centric and anthropocentric attitudes and apathy in relation to the environment. This approach consisted of listing 5 statements that indicated conservative attitudes, 5 indifferent attitudes, and 5 innovative attitudes. The participants would then indicate their degree of agreement or disagreement with each statement on a scale of 1 to 5 (a type of Likert scale) with $\mathbf{1}=$ totally agree to $\mathbf{5}=$ totally disagree.

\section{Statistical analyses}

The statistical data of the acceptability analyses were processed using Statistica 7.0 software, with the normality and homoscedasticity of the variances being submitted to Kolmogorov-Smirnov and Levene tests respectively. 
The acceptability data for appearance, odor, texture and overall evaluation of Spirulina presented in natura, dry, and added to prepared foods were analyzed using the Kruskal-Wallis test at a 5\% confidence level. The attitude data was evaluated using Principal Component Analysis with Varimax rotation, using Programa SPSS software, to verify the factorial structures of the two constructs: considered open to changes in terms of new types of foods, or refractory to changes. We also calculated in these analyses the Cronbach's Coefficient Alpha to verify its index of internal consistency, thus verifying the congruence of each item with the other items of each instrument.

\section{RESUlts AND DISCUSSION}

\section{Microbiological analyses of the Spirulina platensis biomass}

The microbiological analyses of the $S$. platensis biomass did not indicate the development of any of the detrimental microorganisms cited in the RDC $\mathrm{n}^{\circ} 12$ norms of the National Agency of Health Monitoring, being therefore within the acceptable limits for human consumption and admissible for addition to foodstuffs.

\section{Acceptability and purchase intention}

The data of the sensorial analyses of Spirulina in the offered forms of in natura, dry, and premixed in foods (10\% biomass) demonstrated significant differences in terms of odor $(\mathrm{H}=126.5472 ; \mathrm{df}=2 ; \mathrm{p} £ 0.01)$, appearance $(\mathrm{H}=20.02136 ; \mathrm{df}=2 ; \mathrm{p} £ 0.01)$, texture $(\mathrm{H}=83.88218 ; \mathrm{df}=2 ; \mathrm{p} £ 0.01)$, and their overall evaluation $(\mathrm{H}=61.09604$; $\mathrm{df}=2 ; \mathrm{p} £ 0.01)$, as can be seen in Figure 1 .

Figure 1. Mean values of the scores of the attributes appearance, odor, texture, and overall evaluation based on acceptance tests of $S$. platensis presented in natura (white), dry (grey), and premixed in foods (black) $(10 \%$ biomass). Similar letters indicate no statistical difference.

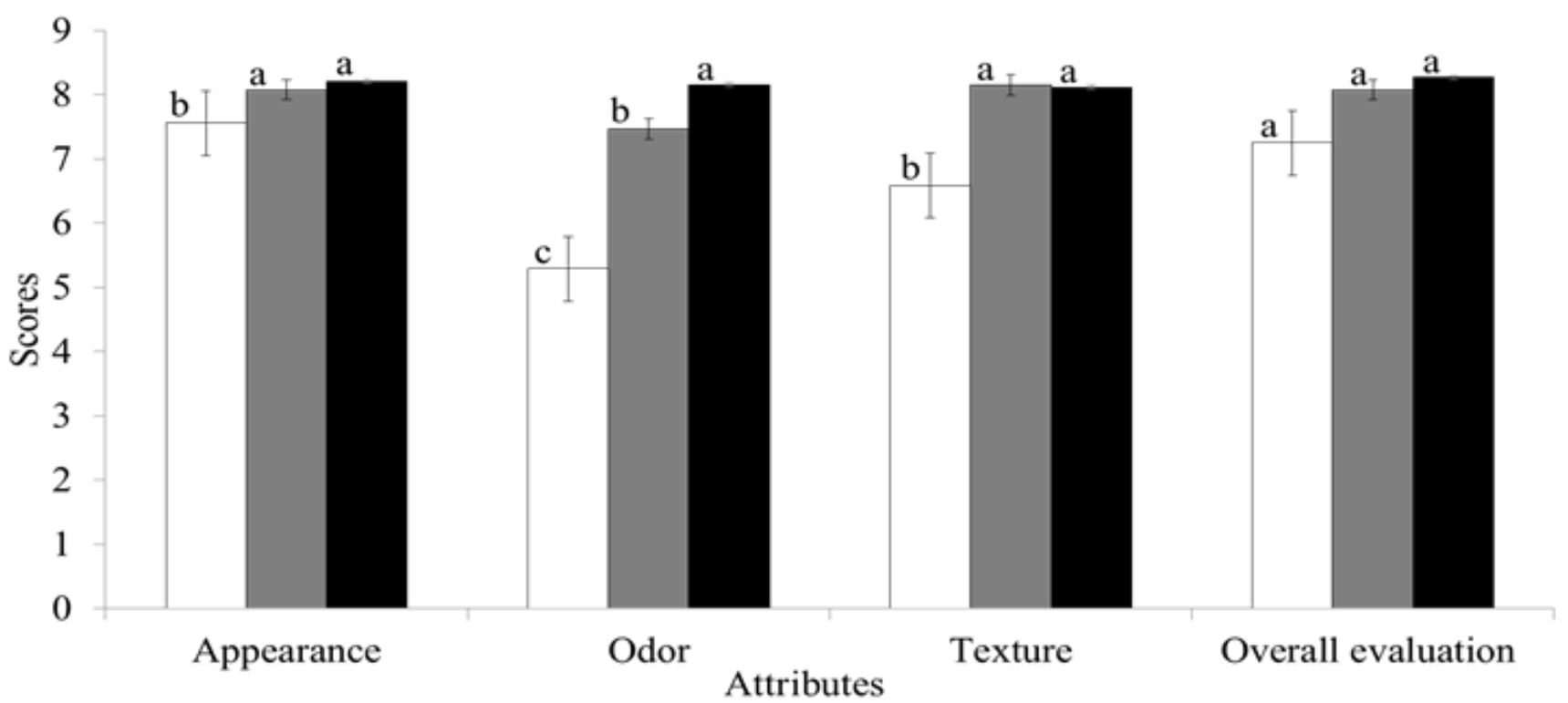

The acceptability indices of Spirulina platensis in the offered forms (in natura, dry, and premixed in foods) revealed that only its odor in the in natura state did not achieve a satisfactory minimal percentage of acceptance (Figure 2) as proposed by Teixeira et al. (1987). 
Figure 2. Acceptability indices of $S$. platensis presented in natura (white), dry (grey), and premixed in foods (black) $(10 \%$ biomass $)$.

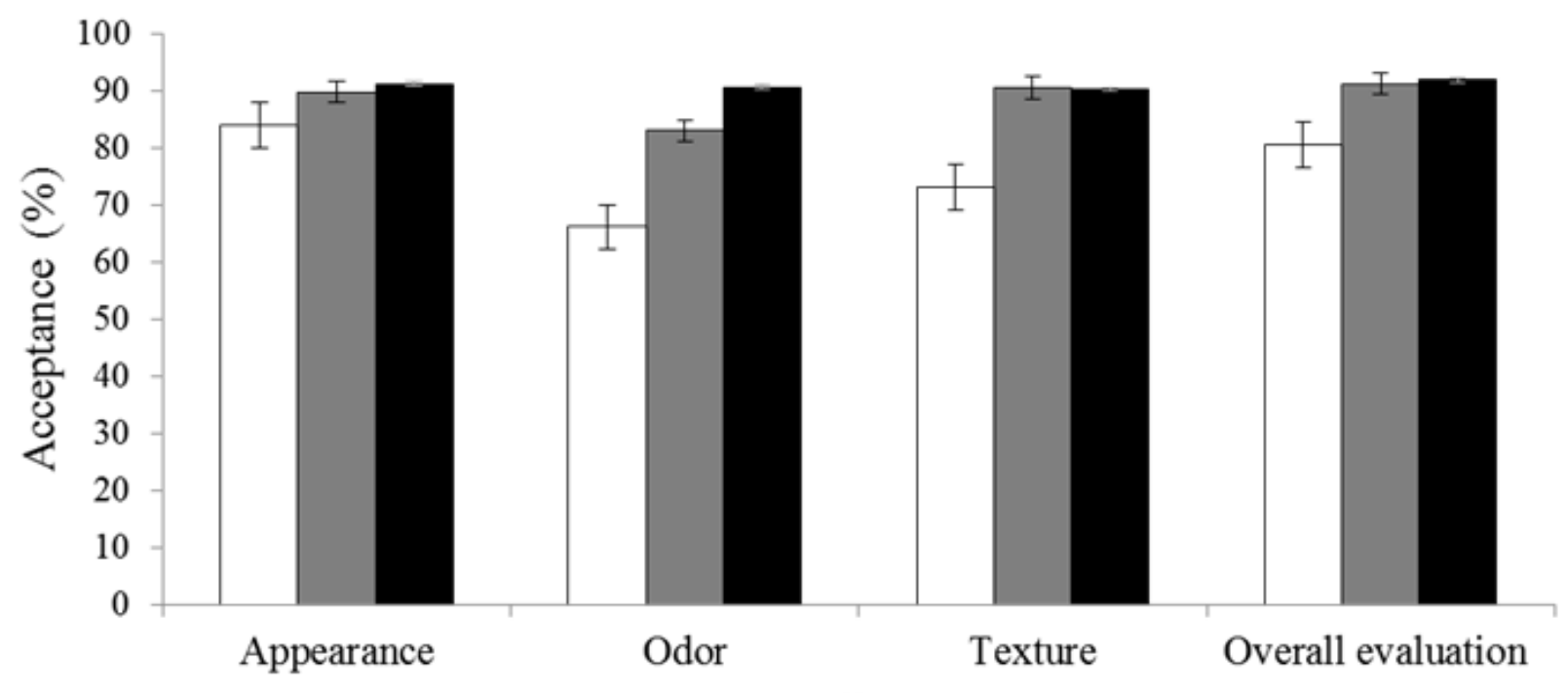

Attributes

In terms of the intention to purchase Spirulina in its dry form or premixed in foods, most of the agricultural workers (88\%) indicated that they "would purchase", 10.67\% indicated that they "would possibly purchase", and $1.33 \%$ indicated that they "might purchase/might not purchase". None of them indicated that they "would never purchase" or "probably would never purchase". Other researchers have also reported that Spirulina demonstrated high acceptability. The addition of $1.0 \%, 3.0 \%$ and $5.0 \%$ biomasses of $S$. platensis in cookies yielded 58\%, 50\% and $40 \%$ intentions of purchase respectively (Morais et al. 2006); indices of up to $80.27 \%$ acceptance were also found for noodles enriched with $10 \% \mathrm{~S}$. platensis biomass.

Our results suggest that if technical-educational efforts were directed towards rural agricultural workers in the semiarid region of Brazil in terms of the artisanal production and use of Spirulina platensis it would eventually be possible to firmly establish its acceptability as a food additive. According to El-Dash and Germani (1994), consumers begin to accept new products into their diets (in competition with conventional foodstuffs) when those products are readily available, good tasting, of good quality, and have accessible prices.

The basic diet of inhabitants of the Brazilian semiarid region consists in large part of animal protein (cattle and goats) supplemented with beans, fava beans, corn, and rice. As this same region experiences seasonal protein deficits (due to regularly recurring droughts), it could be favorable to the inclusion of Spirulina.

Blue-green algae can be cultivated ecologically, not generating pollution, soil erosion, water contamination, or the destruction of forests - factors not internalized in the costs of conventional food production. Other advantages to the dissemination of Spirulina culturing among semiarid agricultural workers include the lack of soil fertility requirements, large production areas, excessive energy consumption, or large quantities of water (as this latter resource can be re-utilized - which is extremely important in arid areas).

In order to increase the positive acceptability index of the rural workers it will be necessary to determine how they view the use of Spirulina; as innovators (open to new practices) or as conservatives (preferring to maintain traditional practices)? Questions such as these require the analysis of their attitudes towards Spirulina.

\section{Tests of attitudes towards Spirulina}

The identification of the attitudes of the agricultural workers towards Spirulina was undertaken by adapting a version of the Ecocentric and Anthropocentric Attitude Scale (Thompson and Barton 1994). This adapted version consisted 
of 15 statements distributed between two views: Innovative Attitudes and Conservative Attitudes. The viability of this version was verified using criteria such as the factorality of the data $\left(\mathrm{KMO}=0.554\right.$; Bartlett's test of sphericity: $\mathrm{X}^{2}=$ 364.913; $\mathrm{p}<0.001$ ), considering the possibility of a factorial analysis of the Principal Components.

The number of extracted factors was fixed at two, which presented Eigenvalues greater than 2.26 and 3.35 that together explained $37.47 \%$ of the total variance, emphasizing that factor I (open to change $=$ innovative attitude) explained more than half of the total variance $(22.39 \%)$. A minimum value of 0.30 was established as the cutoff for acceptable saturation. Twelve items were identified as such, with six (15, 13, 14, 4, 8 and 9) corresponding to factors related to openness to changes, and six others $(7,5,1,6,10$, and 2$)$ related to refractory attitudes towards changes; items 3,11 and 12 were excluded as they demonstrated factor loadings inferior to 0.50 .

Cronbach's Alpha coefficient was used to verify the internal consistency index, with $\alpha=0.63$ being defined for factor I and $\alpha=0.65$ for factor II (data presented in Table 1). Although the statistical treatment revealed values slightly below those expected for this scale the items demonstrated consistencies in terms of the adapted scale.

Table 1. Factorial structure of the Attitude Scale related to openness to changes (innovative attitude) and refractory to changes (conservative attitude).

\section{Descriptions of the items}

15. One of the most important reasons for incorporating Spirulina into one's daily diet is to assure a better quality of life.

13. Spirulina can certainly be useful in human and animal nutrition, as well as for other ends, and its cultivation should be encouraged among rural farm workers.

14. One of the most important reasons for cultivating Spirulina is that it can improve the incomes of small-plot farmers.

4. I would like to see more dryland areas being used to raise cows and goats, and for other similar agricultural activities.

8. Everything said about the difficulties facing semiarid farmers is exaggerated.

9. It upsets me that mankind could face future food shortages, and that misery may become amplified, but I don't think that this has much to do with the difficulties we face here in the semiarid region. (r)

7. I don't worry much about ecological problems, as most environmental problems eventually resolve themselves.

5. The government should invest more in northeastern Brazil to promote traditional practices. We don't need new things. The drylands give us all we need.

1. We need to conserve our dryland traditions to guarantee a high quality of life.

6. I don't think the problem of deforestation in the drylands is as serious as people say.

10. The intensive utilization of water in irrigation projects, as is common in many rural areas, doesn't worry me, as it will always be possible to live with droughts.

2. A healthy diet is that which we can purchase every day. Having money makes the difference, as money and food guarantee well-being.

\section{Eingenvalues}

$\%$ Variance

Accumulated \% Variance

Cronbach's Alpha

\section{Factors}

FI FII

0.90

0.77

$0.70 *$

$0.66^{*}$

$0.65^{*}$

$-0.34$

0.75

0.72

$0.56 *$

$0.56^{*}$

$0.54 * \quad 0.30$

$0.51 *$

0.26

FI and FII define the factor loadings for the Principal Component Analyses with Varimax rotation; FI= open to changes and FII= refractory to changes; $*=$ saturation considered acceptable; $\boldsymbol{h}^{2}=$ Commonalities; (r) Reverse item. 
Consistency is improved by excluding item 9 ("It upsets me that mankind could face future food shortages, and that mystery may become amplified, but I don't think that this has much to do with the difficulties we face here in the semiarid region") from Factor I, with $\alpha=0.67$ becoming slightly satisfactory.

As can be seen in Table 2, the highest percentages obtained for innovative attitudes appeared in items 1 "totally agree" and 2 "partially agree", while for conservative attitudes the highest percentages were observed for items 3 "partially disagree" and 4 "totally disagree". This suggests a strong openness to innovation, although traditional biases still exist.

Table 2. Frequencies (\%) of the scores obtained in the test for innovative or conservative attitudes. Red highlighting $=$ greatest percentage score

\begin{tabular}{lccccc}
\hline Item & \multicolumn{5}{c}{ Scores } \\
\hline Innovative attitudes & 1 & 2 & 3 & 4 & 5 \\
\hline Item 15 & $\mathbf{7 8 . 7}$ & 21.3 & --- & --- & --- \\
Item13 & $\mathbf{6 8 . 7}$ & 32.0 & --- & --- & --- \\
Item 14 & $\mathbf{6 8 . 0}$ & 30.7 & --- & 1.3 & --- \\
Item 4 & $\mathbf{4 2 . 7}$ & 26.7 & --- & 9.3 & 21.3 \\
Item 8 & $\mathbf{3 6 , 0}$ & 25.3 & 6.7 & 20.0 & 12.0 \\
Item 9 & 9.3 & $\mathbf{5 4 . 7}$ & 4.0 & 28.0 & 4.0 \\
\hline Conservative attitudes & & & & & \\
\hline Item 7 & 2.7 & 2.7 & --- & 9.3 & $\mathbf{8 5 . 3}$ \\
Item 5 & 2.7 & 30.7 & --- & $\mathbf{6 4 . 0}$ & 2.7 \\
Item 1 & $\mathbf{4 6 . 7}$ & 40.0 & --- & 4.0 & 9.3 \\
Item 6 & 2.7 & 6.7 & 1.3 & 5.3 & $\mathbf{8 4 . 0}$ \\
Item 10 & --- & --- & --- & 8.0 & $\mathbf{9 2 . 0}$ \\
Item 2 & 18.7 & 8.0 & --- & $\mathbf{5 8 . 7}$ & 14.7 \\
\hline
\end{tabular}

Highlights in bold $=$ highest percentage by score

The results of both the acceptability tests of Spirulina and the attitudes of the rural agricultural workers showed strong innovative characteristics (although with persistent signs of conservative viewpoints), indicating that they are open to changes in their eating habits. This openness would tend to favor the dissemination of artisanal processes of microalgae cultivation within a framework of technical and political-institutional support. The excedent biomass could be used as fertilizer to improve soil quality and traditional agricultural productivities (Zeenat et al. 1990), or it could be incorporated into the diets of farm animals.

One factor that should be considered as contributing to these results was that when the questionnaires were distributed the region was suffering from a considerable lack of water resources, with consequent reductions of subsistence farm production - which may have obliged some of the farmers to reconsider their options for survival during drought situations.

It will not, however, be an easy task to transform traditional production processes in the semiarid region, but success is possible if support systems are gradually implanted. The famous Mahatma Gandhi Ashram in Karla, India, established a domestic pilot project that integrated the productions of compost, fish, and Spirulina; the compost and fish were sold to local inhabitants and the Spirulina shipped to Bombay where it was distributed to children in the form of cookies and noodles (Prasad 2005). In Farende, Togo (western Africa) solar panels were installed in a remote village (where exuberant forests, elephants, and tigers once lived) to charge truck batteries that would move paddles aerating the cultivation tanks. The biomass produced was dried in a solar oven and distributed to children in health clinics (Henrikson 2009). 
Although a novelty for the semiarid region of northeastern Brazil, Spirulina is currently consumed in more than 40 countries around the world in a number of different forms (Belay 1993; Henrikson 2010), including in personal hygiene products (such as skin lotions and shampoos) and as a supplement for fish, aquatic animals, birds, dogs, and cats (Henrikson 2010). Spirulina produces a complex mix of proteins containing all of the essential amino acids, although with reduced quantities of methionine, cystine, and lysine when compared to traditional protein sources such as meat, eggs, or milk - but still superior to all other vegetable proteins (FAO 2008). Spirulina is rapidly digested, and two or more soup spoons of the extract can be consumed daily as supplements in fruit juices and vegetables, as it is a secure natural food source and rapidly digested.

A number of clinical studies using Spirulina have been undertaken with children suffering from severe proteincaloric malnutrition in Vietnam, Zaire, the Central African Republic, and Ruanda, including in situations with manifestations of kwashiorkor and marasmus - and in all of these cases there were notable health improvements, indicating that this supplement was much more effective than soybeans (Henrikson 2009). Just a few grams of Spirulina per day is sufficient to supply the nutritional requirements of a child, which means that each square meter of Spirulina cultivated in localities in warm climates could supply the daily nutritional requirements of 2-3 children during one year (Ardiet and Weid 2007).

The ingestion of the fresh biomass of Spirulina in the form of a paste is highly recommended, as it does not have any significant taste or smell (as compared to the dried product). Eating habits are usually difficult to alter, but can often be more easily initiated with children. Once convinced of the qualities of Spirulina, mothers could incorporate it into their children's diets in soups, puddings, sweets, etc.

In cases of under-nutrition, the effects of ingesting Spirulina are rapidly perceived (Belay 2002; Simpore et al. 2006; Sotiroudis and Sotiroudis 2013), which is a tremendous stimulus to its acceptance. The dry biomass of Spirulina has reduced acceptance, however, due to its strong characteristic smell. It can nonetheless be incorporated into many foods with wide acceptability.

With the development of local artisanal production projects it will be possible to stimulate a local demand for Spirulina, thus generating additional income for small producers. The dry biomass could also be sold in open markets and supermarkets in the region in the same way as manioc flour, beans, and corn meal are commercialized today.

\section{Conclusions}

The present research indicated elevated acceptance of Spirulina platensis among rural agricultural workers in the semiarid region of Paraiba State in northeastern Brazil in the three forms examined: fresh biomass, dry biomass, and dry biomass added to pre-prepared foods - indicating that $S$. platensis cultivation could be introduced into those rural communities.

The attitude tests concerning Spirulina, together with the results of the acceptability tests, indicated a potential openness to dietary changes among rural communities in the semiarid region of Paraíba State, suggesting that public policies supporting the development of artisanal cultures of Spirulina could provide an additional source of food protein and income for those rural populations.

\section{ACKNOWLedgments}

The authors would like to thank the unionized agricultural workers in the municipality of Frei Martinho, Paraíba State, Brazil, who participated in this research project, and the DAAD for awarding a Masters scholarship to the first author. 


\section{REFERENCES}

Belay A, Ota Y, Miyakawa K, Shimamatsu H. 1993. Current knowledge on potential health benefits of Spirulina. Journal of Applied Phycology, 5: 235-241.DOI https://doi.org/10.1007/BF00004024.

Belay A. 2002. The Potential Application of Spirulina (Arthrospira) as a Nutritional and Therapeutic Supplement in Health Management. Journal of the Academy of Nutrition and Dietetics, 5:27-49.

Brasil. 2003. Ministério da Agricultura, Pecuária e Abastecimento. Secretaria de Defesa Agropecuária (Dispoa). Instrução Normativa ${ }^{\circ}$ 62, de 26 de agosto de 2003. Métodos analíticos oficiais para análises microbiológicas para controle de produtos de origem animal e água. Diário Oficial da União. Brasília.

El-Dash A and Germani R. 1994. Tecnologia de Farinhas Mistas: Uso de Farinhas Mistas na Produção de Biscoitos. Brasília: EMBRAPA - SPI 6.

El-Sayed AFM. 1994. Evaluation of soybean meal, spirulina meal and chicken offal meal as protein sources for silver seabream (Rhabdosargus sarba) fingerlings. Aquaculture, 127:169-176. DOI https://doi.org/10.1016/00448486(94)90423-5.

FAO. 2008. The state of food and agriculture. Biofuels: prospects, risks and opportunities. Food and Agriculture Organization of the United Nations. Rome.

Habib MAB, Parvin M, Huntington TC and Hasan MR. 2008. A review on culture, production and use of spirulina as food for humans and feeds for domestic animals and fish. FAO Fisheries and Aquaculture Circular 1034.

Henrikson R. 2009. Earth Food Spirulina: How this remarkable blue-green algae can transform your health and our planet. Ronore Enterprises, California.

Henrikson R. 2010. Spirulina World Food: How this microalgae can transform your health and our planet? Ronore Enterprises, California.

Hoff FH and Snell TW. 2009. Plankton Culture Manual. 5 ed. Dade City: Florida.

Ardiet D and Weid D. 2007. Spirulina as a food complement for health and cognitive development, Antenna Technologies. Available in: http://www.antenna.ch/en/medias/Nutrition-et-d\%C3\%A9veloppement-cognitif_ Antenna-Technologies_2007.pdf. Accessed on: December 18, 2015.

FDA. 2002. GRAS Notification for Spirulina Microalgae. Available in: http://www.fda.gov/downloads/Food/ IngredientsPackagingLabeling/GRAS/NoticeInventory/UCM265861. Accessed on: December 15, 2015.

Koníčková R, Vaňková K, Vaníková J, Váňová K, Muchová L, Subhanová I, Zadinová M, Zelenka J, Dvořák A, Koláŕ M, Strnad H, Rimpelová S, Ruml T, J Wong R, Vítek L. 2014. Anti-cancer effects of blue-green alga Spirulina platensis, a natural source of bilirubin-like tetrapyrrolic compounds. Annals of Hepatollogy, Mar-Apr 13:27383.

Layam A and Reddy CLK. 2007. Antidiabetic property of Spirulina. Diabetologia Croatica, 35:29-33.

Mao TK, Van de Water J and Gershwin ME. 2003. Effect of Spirulina on the secretion of cytokines from peripheral blood mononuclear cells. Journal of Medicinal Food, 3:135-140. Doi 10.1089/jmf.2000.3.135. 
Mohan IK, Khan M, Shobha JC, Naidu MUR, Prayag A, Kuppusamy P and Kutala VK. 2006. Protection against cisplatin-induced nephrotoxicity by Spirulina in rats. Cancer Chemotherapy and Pharmacology, 58(6):802-808. DOI 10.1007/s00280-006-0231-8.

Moorhead, K, Capelli, B and Cysewski, GR. 2006. Spirulina Nature's Superfood. Cyanotech Corporation.

Morais MG, Miranda MZ and Costa JAV. 2006. Biscoitos de chocolate enriquecidos com Spirulina platensis: características físico-químicas, sensoriais e digestibilidade. Alimentos e Nutrição, 17:323-328.

Juárez-Oropeza MA, Mascher D, Torres-Durán PV, Farias JM and Paredes-Carbajal MC. 2009. Effects of dietary Spirulina on vascular reactivity. Journal of Medicinal Food, 12: 15-20. DOI 10.1089/jmf.2007.0713.

Ozdemir G, Karabay NU, Dalay MC and Pazarbasi B. 2004. Antimicrobial activity of volatile component and various extracts of Spirulina plantensis. Phytotherapy Research, 18:754-757. DOI 10.1002/ptr.1541.

Prasad CS. 2005. Science and Technology in Civil Society Innovation Trajectory of Spirulina Algal Technology. Economic and Political Weekly, 4063-3372.

Ramakrishnan R. 2013. Antiviral properties of cyanobacterium, Spirulina platensis- A review. International Journal of Medicine and Pharmaceutical Sciences, 3: 1-10.

Simpore J, Kabore F, Zongo F et al. 2006. Nutrition Rehabilitation of Undernourished Children Utilizing Spiruline and Misola. Nutrition Journal, 5:3. DOI https://doi.org/10.1186/1475-2891-5-3.

Sotiroudis TG and Sotiroudis GT. 2013. Health aspects of Spirulina (Arthrospira) microalga food supplement. Journal of the Serbian Chemical Society, 78:395 - 405 . DOI https://doi.org/10.2298/JSC121020152S.

Stone H and Sidel J. 1993. The role of sensory evaluation in the industry. Food Quality and Preference, 4(2):6573. DOI https://doi.org/10.1016/0950-3293(93)90314-V.

Teixeira E, Meinert EM e Barbetta PA. 1987. Análise sensorial de alimentos. Editora da UFRS Florianópolis.

Thompson SCG and Barton MA. 1994. Ecocentric and anthropocentric attitudes toward the environment. Journal of Environmental Psychology, 14:149-157. DOI https://doi.org/10.1016/S0272-4944(05)80168-9.

Yang HN, Lee EH and Kim HM. 1997. Spirulina platensis inhibits anaphylactic reaction. Life Sciences, 61(13):1237 - 1244. DOI: https://doi.org/10.1016/S0024-3205(97)00668-1.

Zarrouk C. 1966. Contribution l'e'tude d'une cyanophyce : influence de divers facteurs physiques et chimiques sur la croissance et la photosynthe`se de Spirulina maxima (Setch et Gardner) Geitler. Thesis (PhD), Faculty of Science, University of Paris.

Zeenat R, Sharma VK and Rizvi Z. 1990. Synergistic effect of cyanobacteria and DAP on tomato yield. Science and Culture, 56:129-131. 